Short Communication

\title{
Electrochemical Determination of Vanillin in Food Samples Using MgO/SWCNTs-ionic Liquid Modified Electrode
}

\author{
Maryam Abbasghorbani \\ Gas Division, Research Institute of Petroleum Industry, P.O. Box 14665-137, Tehran, Iran \\ E-mail: aghorbani2003@yahoo.com
}

doi: $10.20964 / 2017.12 .39$

Received: 25 August 2017 / Accepted: 8 October 2017 / Published: 12 November 2017

The development of a novel electrochemical sensor, based on modification of the carbon paste electrode with $\mathrm{MgO} / \mathrm{SWCNTs}$ nanocomposite and 1-butyl-3-methylimidazolium hexafluoro phosphate $\left(\mathrm{MgO} / \mathrm{SWCNTs} / \mathrm{BMPF}_{6} / \mathrm{CPE}\right)$ has been reported. The electro-oxidative behavior of vanillin in food samples at $\mathrm{MgO} / \mathrm{SWCNTs} / \mathrm{BMPF}_{6} / \mathrm{CPE}$ using square wave and linear sweep voltammetry was investigated. The oxidation signal of vanillin at $\mathrm{MgO} / \mathrm{SWCNTs} / \mathrm{BMPF}_{6} / \mathrm{CPE}$ increased when compared with the unmodified electrode. The catalytic current showed a linear relationship with vanillin concentration in the range 0.02 to $800 \mu \mathrm{M}$ with a detection limit of $8.0 \mathrm{nM}$. The $\mathrm{MgO} / \mathrm{SWCNTs} / \mathrm{BMPF}_{6} / \mathrm{CPE}$ was applied for vanillin determination in food samples.

Keywords: Vanillin, MgO/SWCNTs, 1-butyl-3-methylimidazolium hexafluoro phosphate, Modified electrode.

\section{FULL TEXT}

(C) 2017 The Authors. Published by ESG (www.electrochemsci.org). This article is an open access article distributed under the terms and conditions of the Creative Commons Attribution license (http://creativecommons.org/licenses/by/4.0/). 